OPEN ACCESS

Edited by:

Matteo Balderacchi, Independent Consultant,

Piacenza, Italy

Reviewed by:

Rakesh K. Upadhyay,

United States Department of Agriculture (USDA), United States

Manoj Kumar Solanki,

University of Silesia of

Katowice, Poland

*Correspondence:

Everlon Cid Rigobelo

everlon.cid@unesp.br

Specialty section:

This article was submitted to

Crop Biology and Sustainability,

a section of the journal

Frontiers in Sustainable Food Systems

Received: 18 August 2020 Accepted: 16 March 2021

Published: 16 April 2021

Citation:

Santos RMd and Rigobelo EC (2021)

Growth-Promoting Potential of

Rhizobacteria Isolated From

Sugarcane.

Front. Sustain. Food Syst. 5:596269. doi: 10.3389/fsufs.2021.596269

\section{Growth-Promoting Potential of Rhizobacteria Isolated From Sugarcane}

\author{
Roberta Mendes dos Santos ${ }^{1}$ and Everlon Cid Rigobelo ${ }^{2 *}$ \\ ${ }^{1}$ Agricultural and Livestock Microbiology Post - Graduation Program, School of Agricultural and Veterinarian Sciences, \\ São Paulo State University (UNESP), Jaboticabal, Brazil, ${ }^{2}$ Graduate Program in Agricultural Microbiology, São Paulo State \\ University - Faculdade de Ciências Agrárias e Veterinárias (FCAV)/UNESP, Jaboticabal, Brazil
}

The search for plant growth-promoting rhizobacteria (PGPRs) addresses the ongoing need for new bioinoculants to be used on various agricultural crop species, including sugarcane. Bacterial strains were isolated from the rhizosphere of sugarcane plants and identified by sequencing the $16 \mathrm{~S}$ ribosomal gene. The main indole acetic acid producers were Enterobacter sp. IP11, Enterobacter sp. IP14, and E. asburiae IP24. Achromobacter spanius IP23 presented the highest levels of cellulolytic activity and potassium solubilization. Bacillus thuringiensis IP21 and Staphylococcus saprophyticus IJ8 showed the highest levels of fixed nitrogen. The levels of calcium phosphate and aluminum phosphate in $B$. thuringiensis IP21 were notable, as this strain solubilized 481.00 and $39.33 \mathrm{mg}$ of phosphorus $\mathrm{mL}^{-1}$, respectively; however, for Araxá apatite, the results for $B$. anthracis IP17 were notable (622.99 mg phosphorus $\mathrm{mL}^{-1}$ ), while for iron phosphate solubilization, Enterobacter sp. IP14, which solubilized $105.66 \mathrm{mg}$ phosphorus $\mathrm{mL}^{-1}$ was notable. The $B$. thuringiensis IP21 and Enterobacter sp. IP11 isolates promoted the growth of the tallest sugarcane plants, inducing increases of 14.1 and $10.4 \%$ relative to the control plants, respectively. For shoot dry matter, root dry matter, and total dry matter, plants inoculated with Enterobacter sp. IP14, B. anthracis IP17, and A. spanius IP23 presented higher values than the controls. Furthermore, plants inoculated with $B$. thuringiensis IP21 presented higher root dry matter and total dry matter values, and those inoculated with Enterobacter sp. IP14 also presented higher total dry matter values. These results indicate that bacteria with the potential for use as future inoculants should be investigated since bacteria with plant growth-related characteristics may not impact growth promotion.

Keywords: Saccharum spp., growth promotion, solubilization, IAA, nitrogen, phosphorus, greenhouse

\section{INTRODUCTION}

Sugarcane (Saccharum officinarum L.) is one of the most economically important agricultural crop species, mainly as a source of sugar, and is grown worldwide in tropical and subtropical areas. Brazil is the largest producer of sugarcane in the world, and the 2019/20 harvest was estimated at 642.7 million tons (Conab, 2019). Sugarcane growth and performance are directly impacted by the use of fertilizers; fertilizers are expensive, and their continual use causes damage to the environment (Moutia et al., 2010; Leite et al., 2018). 
An alternative to fertilizers that can reduce costs and environmental impacts is the use of plant growth-promoting rhizobacteria (PGPRs) (Pérez-Montaño et al., 2014). This group of bacteria inhabits the plant rhizosphere and promotes plant growth (Zhou et al., 2016; Riaz et al., 2021).

A wide range of applications of these beneficial rhizobacteria in sugarcane crops have been proposed, and a considerable number of research studies have focused on their functionality and applicability. The results of several studies have shown that the utilization of PGPRs in sugarcane is a great alternative to the challenges of modern agriculture (dos Santos et al., 2020).

PGPRs promote plant growth by direct and indirect mechanisms. The direct mechanisms include assisting plants in obtaining nutrients and modulating the levels of growth-related plant hormones, whereas the indirect mechanisms include inhibiting certain pathogens and protecting plants from future attacks by acting as a biocontrol agent (Glick, 1995; Miliute et al., 2015; Vurukonda et al., 2018; Estrada-Bonilla et al., 2021).

Regarding the acquisition of nutrients, members of some genera of free-living bacteria, such as Azospirillum, Azotobacter, Bacillus, Burkholderia, and Herbaspirillum, are capable of converting atmospheric nitrogen into ammonium and supplying it to plants. These PGPRs can provide nitrogen for agronomically important crop species, such as wheat, sorghum, corn, rice, and sugarcane (Pérez-Montaño et al., 2014; Batista et al., 2021).

Some rhizobacteria also have the ability to solubilize inorganic phosphates that are present in the soil in large amounts in an unavailable form that cannot be absorbed by plants, which limits plant growth. PGPRs can convert phosphorus into a soluble form that is usable by plants (Gaind, 2016; Ramakrishna et al., 2019). Phosphorus solubilization can occur by different mechanisms, most commonly by the production of organic acids such as acetic acid, malic acid, lactic acid, succinic acid, oxalic acid, and tartaric acid (Ahemad and Kibret, 2014; Patel and Desai, 2015). In addition, PGPR inoculation can increase the absorption of various other nutrients by plants, including $\mathrm{Ca}, \mathrm{K}, \mathrm{Fe}, \mathrm{Cu}, \mathrm{Mn}$, and $\mathrm{Zn}$ (Mantelin and Touraine, 2004).

Several PGPRs can alter root architecture and promote root development by increasing nutrient absorption and accumulation due to their phytohormone-synthesizing capability (Boiero et al., 2007; Dar et al., 2021). The growth of plants inoculated with indole acetic acid (IAA)-producing rhizobacteria is generally significantly greater than that of uninoculated plants (Kaymak et al., 2008).

PGPRs indirectly promote plant growth when they decrease or interrupt the harmful effects of phytopathogens. Under biotic stress, rhizobacteria can trigger the induction of systemic resistance, and under abiotic stress, PGPRs can protect against unfavorable environmental conditions (Jha et al., 2011; Gururani et al., 2013; Vacheron et al., 2013; Glick, 2014; Nadeem et al., 2014) by producing antibiotics, toxins, siderophores, hydrolytic enzymes, and volatile organic antimicrobial compounds (Sheoran et al., 2015).

The success of using PGPRs as inoculants for agricultural crops depends not only on the growth-promoting abilities of rhizobacteria but also on plant-microorganism interactions, which are influenced by various factors, such as the composition of exudates released by plant roots as well as soil health, gene expression patterns, cell communication, plant genotypes, and rhizosphere colonization capability (Danhorn and Fuqua, 2007; Meneses et al., 2011; Alquéres et al., 2013; Beauregard et al., 2013).

In view of these findings, the present study aimed to identify new bacterial strains isolated from sugarcane that have the ability to promote plant growth for use as inoculants in sugarcane cultivation.

\section{MATERIALS AND METHODS Bacterial Strain Isolation}

Sixty bacterial strains were isolated from the rhizospheres of the sugarcane plant varieties IAC95-5000 and RB86-7515 in the municipality of Jaboticabal-SP; 62 colonies were obtained from the rhizospheres of the varieties CTC9 and RB85-5156 in the municipality of Frutal-MG; and 45 colonies were isolated from the rhizospheres of the varieties IAC91-1099 and CTC4 in the municipality of Pirajuba-MG. A total of 167 bacterial colonies were isolated from the three locations, of which 58 could fix nitrogen, 20 could produce indole acetic acid, 53 had cellulolytic activity, and 17, 26, 44, 33, and 51 could solubilize potassium, calcium phosphate, aluminum phosphate, iron phosphate, and Araxá apatite, respectively.

Bacteria from rhizospheric soil samples were isolated by serial dilution (Wollum, 1982; Vieira and Nahas, 2005). After incubation, bacterial colonies were picked, placed in SMAcontaining test tubes and refrigerated for later use.

The strains were characterized on the basis of their growthpromoting abilities as described below.

\section{Biological Nitrogen Fixation (BNF)}

For BNF quantification, $650 \mu \mathrm{L}$ of each strain was added to $15 \mathrm{~mL}$ of $\mathrm{NFb}$ semisolid media, which was then incubated at $30^{\circ} \mathrm{C}$ for 5 days at $180 \mathrm{rpm}$. Thereafter, $9.5 \mathrm{~mL}$ of the resulting solution (medium + cell content) was poured into tubes for digestion using the semimicro-Kjeldahl method. After this process, the solutions were distilled and titrated to quantify the total nitrogen produced by each bacterial strain. Fixed nitrogen is expressed as milligrams of nitrogen per milliliter (Tedesco et al., 1995).

\section{Phosphate Solubilization}

The phosphate solubilizing ability of the bacterial strains was measured in liquid media (Nahas et al., 1994) comprising $0.1 \mathrm{~g}$ of $\mathrm{NaCl}, 1 \mathrm{~g}$ of $\mathrm{NH}_{4} \mathrm{Cl}, 0.2 \mathrm{~g}$ of $\mathrm{KCl}, 0.2 \mathrm{~g}$ of $\mathrm{CaCl}_{2}, 2 \mathrm{H}_{2} \mathrm{O}, 0.1 \mathrm{~g}$ of $\mathrm{MgSO}_{4} \cdot 7 \mathrm{H}_{2} \mathrm{O}, 10 \mathrm{~g}$ of glucose, $0.5 \mathrm{~g}$ of yeast extract, and $1,000 \mathrm{~mL}$ of $\mathrm{H}_{2} \mathrm{O}(\mathrm{pH}$ 7) supplemented with a single insoluble/slightly soluble source of phosphorus. Four sources of phosphate were tested, namely, $\mathrm{CaPO}_{4}$, Araxá apatite $\left(3 \mathrm{Ca}_{3}\left(\mathrm{PO}_{4}\right)_{2}, \mathrm{CaF}_{2}\right)$, $\mathrm{AlPO}_{4}$, and $\mathrm{FePO}_{4}$ in amounts of $5,5,3.5$, and $4.33 \mathrm{~g}$ per $1 \mathrm{~L}$ of medium, respectively (Silva Filho and Vidor, 2000).

Erlenmeyer flasks containing liquid media were incubated for $48 \mathrm{~h}$ at $28^{\circ} \mathrm{C}$ with shaking at $180 \mathrm{rpm}$ (Nautiyal, 1999). After incubation, $5 \mathrm{~mL}$ of each sample was transferred to tubes, which were then centrifuged at 9,000 rpm for $15 \mathrm{~min}$. Thereafter, $1 \mathrm{~mL}$ of the supernatant of each strain, $4 \mathrm{ml}$ of distilled water, and 
$1 \mathrm{ml}$ of an ammonium molybdate-vanadate reagent were added to a new tube and subsequently read by a spectrophotometer at $470 \mathrm{~nm}$ (Malavolta et al., 1989). Phosphorus values were obtained using a standard curve generated with known $\mathrm{KH}_{2} \mathrm{PO}_{4}$ concentrations, and the results are presented in milligrams of phosphorus per milliliter.

\section{Potassium Solubilization}

Potassium solubilization was measured using Ekosil ${ }^{\circledR}$ fertilizer, which is an alternative source of $\mathrm{K}$ produced from a type of volcanic rock known as phonolite that contains $8 \%$ soluble $\mathrm{K}_{2} \mathrm{O}$ (Yoorin, 2018).

To quantify potassium solubilization by the bacterial strains, Aleksandrov media (Hu et al., 2006) supplemented with Ekosil ${ }^{\circledR}$ was used. Approximately $1 \mathrm{ml}$ of each strain was inoculated in $50 \mathrm{ml}$ of Aleksandrov media and then incubated at $30^{\circ} \mathrm{C}$ at $180 \mathrm{rpm}$ for 5 days. Shortly thereafter, the bacterial samples were filtered through No. 1 Whatman filter paper, and the amount of solubilized $\mathrm{K}$ was determined by flame photometry (Pachaiyappan and Janarthanam, 2007). The results are expressed in milligrams of $\mathrm{K}$ per liter.

\section{IAA Production}

IAA production was measured according to the methods of Sarwar and Kremer (1995) with slight modifications. The strains were incubated in $20 \mathrm{~mL}$ of DYGS (dextrose, yeast, glucose, sucrose) media supplemented with $5 \mathrm{~mL}$ of L-tryptophan for $48 \mathrm{~h}$ at $28^{\circ} \mathrm{C}$ under constant agitation at $120 \mathrm{rpm}$ in the absence of light. After this period, $5 \mathrm{~mL}$ of each bacterial culture was centrifuged at $10,000 \mathrm{rpm}$ for $10 \mathrm{~min}$, and $2 \mathrm{~mL}$ of the supernatant was subsequently transferred to a test tube containing $2 \mathrm{~mL}$ of $2 \%$ Salkowski's reagent (v/v) $\left(0.5 \mathrm{M} \mathrm{FeCl}_{3}\right.$ in $35 \%$ perchloric acid), which was then incubated for $30 \mathrm{~min}$ in the dark.

IAA production was determined by spectrometry at $530 \mathrm{~nm}$, and IAA levels were obtained using a standard curve generated with known concentrations. The results are expressed in micrograms of IAA per milliliter.

\section{Cellulolytic Activity}

The cellulolytic activity of the bacterial strains was measured using Ramachandra media (Ramachandra et al., 1987) supplemented with $5 \%$ carboxymethyl cellulose (CMC). The strains were grown for $48 \mathrm{~h}$ at $30^{\circ} \mathrm{C}$ under agitation at $170 \mathrm{rpm}$ and then centrifuged at $4,000 \times \mathrm{g}$ for $10 \mathrm{~min}$. The supernatant was then collected and analyzed using DNS (dinitrosalicylic acid solution). Total cellulase activity was quantified by measuring the amount of reducing sugars released during the degradation of a strip of No. 1 Whatman filter paper measuring $1.0 \times 6.0 \mathrm{~cm}$ (Ghose, 1987).

The standard curve for enzymatic determination was generated by glucose determination (Miller, 1959). One enzyme activity unit (U) was defined as the amount of enzyme capable of releasing $1 \mathrm{mg}$ reducing sugar per min at $50^{\circ} \mathrm{C}$, and enzyme activity is expressed as units per milliliter.

\section{Molecular Identification of Bacterial Strains}

Strains that showed the most consistent results with the previously described properties were identified following the protocol of the Quick-DNA Universal Extraction Kit (ZymoResearch, cat nos. D4068 and D4069) (Sambrook et al., 1989). For identification, PCR products were purified using the Wizard ${ }^{\circledR}$ SV Gel and PCR Clean-up System Kit and sequenced using universal primers. The sequences were edited using the Biological Sequence Alignment Editor - BioEdit (Hall, 1999), and the consensus sequence was obtained using the BLAST ${ }^{\circledR}$ tool (Altschul et al., 1990) and compared with the National Center for Biotechnology Information (NCBI) GenBank database. The resulting phylogenetic trees were constructed using MEGA7 ${ }^{\circledR}$ software (Tamura et al., 2004).

Then, the characterized strains were lyophilized and stored at $-80^{\circ} \mathrm{C}$.

\section{Data Analysis}

The data were analyzed by analysis of variance ( $F$-test), and the average results for each treatment were compared by Tukey's test at the 5\% probability level using AgroEstat version 1.0 software (Barbosa and Maldonado, 2010).

\section{Plant Growth Promotion Assay at Greenhouse Experimental Design}

A randomized block design with three replicates and eight treatments was used. A total of 24 pots were used, and each pot was considered one experimental unit. The treatments were described in Table 2.

Initially, ministalks were planted in sprouting boxes in a greenhouse. After 15 days, the plants that had developed were transplanted into pots with a volumetric capacity of 5 liters and maintained outdoors for 60 days.

The experiment used ministalks (the region where the bud is located) of 10-month-old RB 5201 sugarcane plants. The ministalks were planted in eight sprouting boxes (one per treatment). The sprouting boxes were filled with a 1:1 mixture of sand:vermiculite. The ministalks were germinated to ensure that the sugarcane plants would be at the same vegetative stage of development when they were transplanted into pots (Figure 1). The pots were filled with a 2-cm layer of gravel and soil. The soil was classified as a Eutrophic Red Latosol and had the following chemical properties: a $\mathrm{pH}$ of 6.9 (in $\left.\mathrm{CaCl}_{2}\right) ; 10.0 \mathrm{~g} \mathrm{dm}^{-3}$ organic matter (OM); $14.0 \mathrm{mg} \mathrm{dm}^{-3} \mathrm{P}$ resin; 0.7, 79.0, and 13.0 mmolc $\mathrm{dm}^{-3} \mathrm{~K}, \mathrm{Ca}$, and $\mathrm{Mg}$, respectively; a cation exchange capacity (CEC) of 104.2 mmolc $\mathrm{dm}^{-3}$; a $\mathrm{V}$ of $90 \%$; and an SB of 93.4 mmolc $\mathrm{dm}^{-3}$.

The precipitation and irrigation during the experimental period totaled $816.4 \mathrm{~mm}$ (620.2 and $196.2 \mathrm{~mm}$ of precipitation and irrigation, respectively). The average maximum and minimum temperatures during the period were 27.3 and $13.5^{\circ} \mathrm{C}$, respectively. The identifications of sugarcane rhizospheric bacteria are shown in Table 1 and the sugarcane pot treatments are shown in Table 2. 


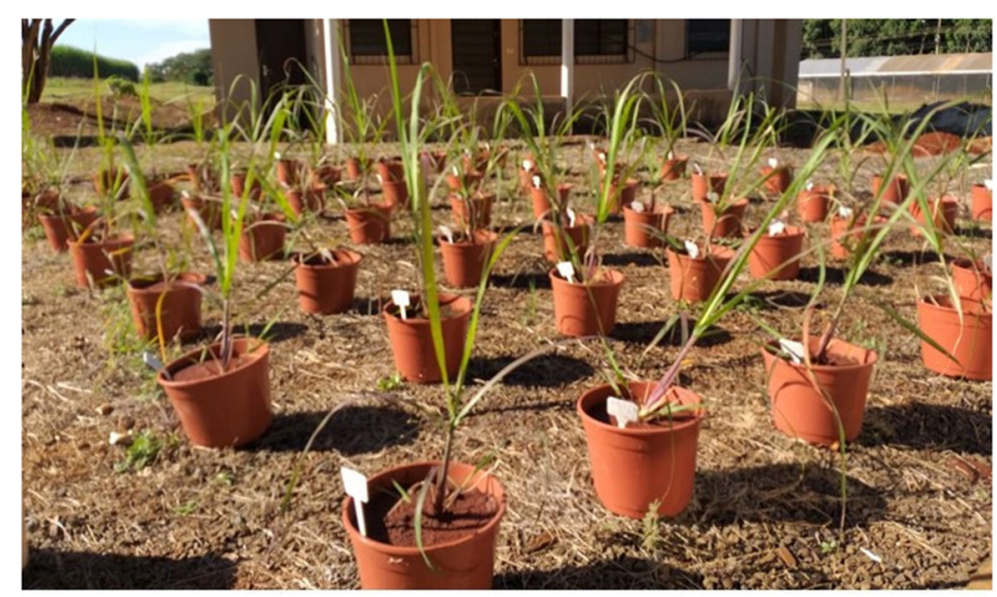

FIGURE 1 | Experimental trial showing sugarcane in pots.

TABLE 1 | Identification of sugarcane rhizospheric bacteria using NCBI BLAST-N of $16 \mathrm{~S}$ rRNA gene sequences.

\begin{tabular}{llc}
\hline Isolate & Species identification & Identity (\%) \\
\hline IJ8 & Staphylococcus saprophyticus NR_114090.1 & 99.76 \\
& Staphylococcus saprophyticus MG694483.1 & 100.00 \\
IP11 & Enterobacter sp. KR558701.1 & 99.85 \\
& Enterobacter sp. HM748078.1 & 99.85 \\
IP14 & Enterobacter sp. KR558701.1 & 96.34 \\
& Enterobacter sp. HM748078.1 & 96.34 \\
IP17 & Bacillus anthracis MK575034.1 & 99.88 \\
& Bacillus anthracis AF290553. & 99.88 \\
IP21 & Bacillus thuringiensis NR_112780.1 & 99.79 \\
& Bacillus thuringiensis KT159186.1 & 99.68 \\
IP23 & Achromobacter spanius MN007235.1 & 99.29 \\
& Achromobacter spanius NR_025686.1 & 99.29 \\
IP24 & Enterobacter asburiae MG571735.1 & 99.84 \\
& Enterobacter asburiae KY316493.1 & 99.84 \\
\hline
\end{tabular}

Query cov. 100\%; E-value 0.0 for all sequences.

TABLE 2 | Sugarcane pot treatments and accession number of Rhizobacteria's sequences deposited at NCBI.

\begin{tabular}{lll}
\hline Treatment & Inoculant & Accession number \\
\hline T1 & Staphylococcus saprophyticus IJ8 & MT764797.1 \\
T2 & Enterobacter sp. IP11 & MT764798.1 \\
T3 & Enterobacter sp. IP14 & MT764799.1 \\
T4 & Bacillus anthracis IP17 & MT764800.1 \\
T5 & Bacillus thuringiensis IP21 & MT764801.1 \\
T6 & Achromobacter spanius IP23 & MT764802.1 \\
T7 & Enterobacter asburiae IP24 & MT764803.1 \\
T8 & Controle (Sem inoculação) & - \\
\hline
\end{tabular}

\section{Soil Fertilization}

For soil fertilization, the equivalent of $60 \mathrm{~kg} \mathrm{ha}^{-1}$ urea $(0.74 \mathrm{~g}$ pot $^{-1}$ ) and $200 \mathrm{~kg} \mathrm{ha}^{-1}$ potassium chloride $(1.89 \mathrm{~g}$ per pot) were applied in two applications: one at the time of planting and another as a topdressing at 30 days after planting. At the time of planting, $140 \mathrm{~kg} \mathrm{ha}^{-1}$ simple superphosphate $\left(4.16 \mathrm{~g} \mathrm{pot}^{-1}\right)$, $5 \mathrm{~kg} \mathrm{ha}^{-1}$ zinc sulfate $\left(0.15 \mathrm{~g} \mathrm{pot}^{-1}\right), 2 \mathrm{~kg} \mathrm{ha}^{-1}$ boric acid $(0.065 \mathrm{~g}$ pot $\left.^{-1}\right)$, and $3 \mathrm{~kg} \mathrm{ha}{ }^{-1}$ manganese sulfate $\left(0.057 \mathrm{~g} \mathrm{pot}^{-1}\right)$ were applied. The soil amendment and fertilization amounts were based on the recommendations of a previous study (Raij et al., 1997).

\section{Inoculation}

All previously characterized lyophilized strains were resuspended in nutrient broth and incubated for $24 \mathrm{~h}$ in a BOD oven at $28^{\circ} \mathrm{C}$ to achieve a final concentration of $1 \times 10^{9}$ colony-forming units (CFUs) $\mathrm{mL}^{-1}$.

The first inoculation was carried out after transplanting the sugarcane into pots, and inoculation was conducted every 15 days thereafter. Inoculation was performed via the soil with the aid of a graduated pipette with the addition of $15 \mathrm{~mL}$ inoculum pot ${ }^{-1}$. In the control treatment, no inoculum was added.

\section{Biometric Analysis and Bacterial Counts}

The number of tillers per pot was counted, and the height of the tillers was measured from the base of the plant to the +1 leaf (in accordance with the Kuijper numbering system) using a graduated ruler. The diameter of the tillers was also measured at the base of each tiller close to the ground with the aid of a caliper. The height and diameter of the main tiller were measured.

For the counting of endophytic bacteria, the plants were separated into shoots and roots, which were washed with a water jet to remove the soil. One gram of each vegetative tissue (shoots and roots) sample was subsequently weighed and subjected to superficial disinfection to eliminate epiphytic microorganisms. During this process, both tissues were sequentially immersed in $70 \%$ ethanol for $1 \mathrm{~min}, 3 \%$ sodium hypochlorite solution for $3 \mathrm{~min}$ and $70 \%$ ethanol for $30 \mathrm{~s}$ (Wilkinson et al., 1989). Three rinses were subsequently performed with sterile distilled water. 
Finally, the shoots and roots were aseptically macerated with the aid of a mortar and pestle, after which they were placed in an Erlenmeyer flask containing $3 \mathrm{~mL}$ of $0.1 \% \mathrm{NaCl}$.

For the counting of bacteria present in the soil, $10 \mathrm{~g}$ of rhizospheric soil was added to an Erlenmeyer flask containing $95 \mathrm{~mL}$ of $0.1 \%$ sodium pyrophosphate saline. The contents of all the Erlenmeyer flasks were stirred for $1 \mathrm{~h}$, after which serial dilutions were prepared (Wollum, 1982). One hundred microliters of solutions obtained through triplicate dilution were inoculated into Petri dishes containing nutrient agar medium. The dishes were kept in a BOD oven at $30^{\circ} \mathrm{C}$, and the number of CFUs was counted after 24, 48, and $72 \mathrm{~h}$ (Vieira and Nahas, 2005).

\section{Plant Dry Mass and Soil and Plant Nutrients}

After removing $1 \mathrm{~g}$ of fresh mass to count the endophytic and rhizospheric bacteria, the dry plant mass was measured.

Root dry mass (RDM), shoot dry mass (SDM), and total dry mass (TDM) were measured by separating the plants into shoots and roots, which were washed with a water jet for soil removal. Both types of samples were placed in paper bags and then dried in an oven at $65^{\circ} \mathrm{C}$ until a constant mass was reached. After drying, the mass was measured on a semianalytical scale. To obtain the total dry mass (TDM), the RDM and SDM were summed.

The resin phosphorus content in the soil was determined using spectrophotometric methodology (IAC, 2001). Total nitrogen levels were measured by sulfuric digestion $\left(\mathrm{H}_{2} \mathrm{SO}_{4}\right)$ followed by distillation and titration according to the method of Tedesco et al. (1995). Shoot and root samples used for dry mass determination were ground and then used to measure phosphorus and nitrogen contents. The phosphorus content was measured by means of nitric-perchloric digestion followed by spectrophotometric analysis (Malavolta et al., 1989), and the nitrogen content was measured by sulfuric digestion followed by titration (Malavolta et al., 1989).

From the nitrogen and phosphorus contents of the sugarcane shoots and roots and the dry mass production values, nutrient extraction was calculated by multiplying the nutrient content in grams per kilogram by the dry mass production (in grams).

\section{Data Analysis}

The data were analyzed by analysis of variance ( $F$-test), and the average results for each treatment were compared by Duncan's test at the 5\% probability level using AgroEstat software version 1.0 (Barbosa and Maldonado, 2010).

\section{RESULTS}

\section{Bacterial Strain Abilities IAA Production}

The highest IAA producers were E. asburiae $(56.68 \mu \mathrm{g}$ of IAA $\left.\mathrm{mL}^{-1}\right)$, Enterobacter 1 (55.32 $\mu \mathrm{g}$ of IAA $\left.\mathrm{mL}^{-1}\right)$, and Enterobacter $2\left(53.23 \mu \mathrm{g}\right.$ of IAA $\mathrm{mL}^{-1}$ ), followed by S. saprophyticus $\left(45.3 \mu \mathrm{g}\right.$ of IAA $\left.\mathrm{mL}^{-1}\right)$ and $B$. anthracis $(42.1 \mu \mathrm{g}$ of IAA $\mathrm{mL}^{-1}$ ). The lowest IAA producer was A. spanius (7 $\mu \mathrm{g}$ of IAA $\mathrm{mL}^{-1}$ ), followed by $B$. thuringiensis (30 $\mu \mathrm{g}$ of IAA $\mathrm{mL}^{-1}$ ) (Figure 2A).

\section{Cellulolytic Activity}

The highest cellulolytic activity was observed for A. spanius $\left(0.61 \mathrm{U} \mathrm{mL}^{-1}\right)$, S. saprophyticus $\left(0.58 \mathrm{U} \mathrm{mL}^{-1}\right)$, Enterobacter 1 $\left(0.58 \mathrm{U} \mathrm{mL}^{-1}\right), B$. anthracis $\left(0.57 \mathrm{U} \mathrm{mL}^{-1}\right)$, and $B$. thuringiensis $\left(0.56 \mathrm{U} \mathrm{mL}^{-1}\right)$. The lowest cellulolytic activity was observed for Enterobacter asburiae $\left(0.54 \mathrm{U} \mathrm{mL}^{-1}\right)$ and Enterobacter $2(0.54 \mathrm{U}$ $\mathrm{mL}^{-1}$ ) (Figure 2B).

\section{Biological Nitrogen Fixation (BNF)}

Regarding BNF, the highest levels of nitrogen compounds were observed in plants treated with B. thuringiensis (108.07 $\mu \mathrm{g}$ of $\mathrm{N} \mathrm{mL}^{-1}$ ), S. saprophyticus (105.07 $\mu \mathrm{g}$ of $\mathrm{N} \mathrm{mL}^{-1}$ ), and A. spanius $\left(95.4 \mu \mathrm{g}\right.$ of $\left.\mathrm{N} \mathrm{mL}^{-1}\right)$. The lowest level of nitrogen compounds was observed for those treated with Enterobacter $2(40 \mu \mathrm{g}$ of $\mathrm{N} \mathrm{mL}-1)$, followed by Enterobacter $1\left(51.4 \mu \mathrm{g}\right.$ of $\left.\mathrm{N} \mathrm{mL}^{-1}\right)$ and Enterobacter asburiae (61.5 $\mu \mathrm{g}$ of $\mathrm{N} \mathrm{mL}^{-1}$ ) (Figure 2C).

\section{Potassium (K), $\mathrm{CaPO}_{4}$, and $\mathrm{AlPO}_{4}$ Solubilization}

Regarding $\mathrm{K}$ solubilization, the highest values were observed for A. asburiae ( $17.8 \mathrm{mg}$ of $\mathrm{K} \mathrm{L}^{-1}$ ) and S. saprophyticus (15.2 $\mathrm{mg}$ of $\mathrm{K} \mathrm{L}^{-1}$ ), and the lowest values were observed for E. asburiae ( $3.1 \mathrm{mg}$ of $\left.\mathrm{K} \mathrm{L}^{-1}\right)$, B. thuringiensis $(3.2 \mathrm{mg}$ of $\left.\mathrm{K} \mathrm{L}^{-1}\right)$, Enterobacter $1\left(6.2 \mathrm{mg}\right.$ of $\left.\mathrm{K} \mathrm{L}^{-1}\right)$, Enterobacter $2\left(6.4 \mathrm{mg}\right.$ of $\mathrm{K} \mathrm{L}^{-1}$ ), and B. anthracis $(12.4 \mathrm{mg}$ of $\mathrm{K}$ $\mathrm{L}^{-1}$ ) (Figure 2D).

Regarding $\mathrm{CaPO}_{4}$ solubilization, the highest levels of $\mathrm{P}$ compounds were observed for B. thuringiensis ( $455.1 \mathrm{mg}$ of $\mathrm{P}$ $\mathrm{mL}^{-1}$ ), followed by E. asburiae ( $452.1 \mathrm{mg}$ of $\mathrm{P} \mathrm{mL}^{-1}$ ), and the lowest levels were observed for Enterobacter $1(4.5 \mathrm{mg}$ of $\mathrm{P}$ $\left.\mathrm{mL}^{-1}\right)$, S. saprophyticus $\left(16.5 \mathrm{mg}\right.$ of $\left.\mathrm{P} \mathrm{mL} \mathrm{m}^{-1}\right)$, A. spanius $(7.2 \mathrm{mg}$ of $\left.\mathrm{P} \mathrm{mL} \mathrm{m}^{-1}\right)$, Enterobacter $2\left(9.5 \mathrm{mg}\right.$ of $\left.\mathrm{P} \mathrm{mL}^{-1}\right)$, and B. anthracis (46.5 $\mathrm{mg}$ of $\mathrm{P} \mathrm{mL}^{-1}$ ) (Figure 2E).

Regarding $\mathrm{AlPO}_{4}$ solubilization, the highest values were observed for B. thuringiensis ( $41.5 \mathrm{mg}$ of $\mathrm{P} \mathrm{mL}^{-1}$ ), followed by Enterobacter 2 (38.7 $\mathrm{mg}$ of $\mathrm{P} \mathrm{mL}^{-1}$ ), Enterobacter 1 (31.4 $\mathrm{mg}$ of $\mathrm{P} \mathrm{mL} L^{-1}$ ), and E. asburiae (29.4 $\mathrm{mg}^{\circ} \mathrm{P} \mathrm{mL}^{-1}$ ), and the lowest values were observed for $B$. anthracis $\left(5.3 \mathrm{mg}\right.$ of $\left.\mathrm{P} \mathrm{mL} L^{-1}\right), S$. saprophyticus $\left(5.7 \mathrm{mg}\right.$ of $\left.\mathrm{P} \mathrm{mL}^{-1}\right)$, and A. spanius $(6.1 \mathrm{mg}$ of $\mathrm{P}$ $\mathrm{mL}^{-1}$ ) (Figure 2F).

\section{$\mathrm{FePO}_{4}$ and Araxá Apatite Solubilization}

Regarding $\mathrm{FePO}_{4}$ solubilization, the highest values were observed for Enterobacter $2\left(104.5 \mathrm{mg}\right.$ of $\left.\mathrm{P} \mathrm{mL}^{-1}\right), \quad B$. thuringiensis (79.3 $\mathrm{mg}$ of $\mathrm{P} \mathrm{mL}-1$ ), E. asburiae $(73.4 \mathrm{mg}$ of $\left.\mathrm{P} \mathrm{mL}^{-1}\right)$, Enterobacter $1\left(73.4 \mathrm{mg}\right.$ of $\left.\mathrm{P} \mathrm{mL}^{-1}\right)$, and $S$. saprophyticus (72 mg of $\mathrm{P} \mathrm{mL}-1$ ), and the lowest values were observed for A. spanius ( $4.5 \mathrm{mg}$ of $\mathrm{P} \mathrm{mL}^{-1}$ ) and B. anthracis (6.5 $\mathrm{mg}$ of $\mathrm{P} \mathrm{mL}^{-1}$ ) (Figure 2G).

Regarding Araxá apatite, the highest values were observed for B. anthracis $(650 \mathrm{mg}$ of $\mathrm{P} \mathrm{mL}-1$ ), followed by $B$. thuringiensis (465.2 $\mathrm{mg}$ of $\mathrm{P} \mathrm{mL}-1$ ), Enterobacter 2 (480 $\mathrm{mg}$ of $\mathrm{P} \mathrm{mL}^{-1}$ ), and S. saprophyticus ( $450.4 \mathrm{mg}$ of $\mathrm{P} \mathrm{mL} \mathrm{m}^{-1}$ ), and the lowest values were observed for $A$. spanius $\left(12.3 \mathrm{mg}\right.$ of $\mathrm{P} \mathrm{mL} \mathrm{mL}^{-1}$ ), E. asburiae $\left(14.7 \mathrm{mg}\right.$ of $\left.\mathrm{P} \mathrm{mL}^{-1}\right)$, and Enterobacter 1 (310.2 $\mathrm{mg}$ of $\mathrm{P} \mathrm{mL}^{-1}$ ) (Figure $2 \mathrm{H}$ ). 


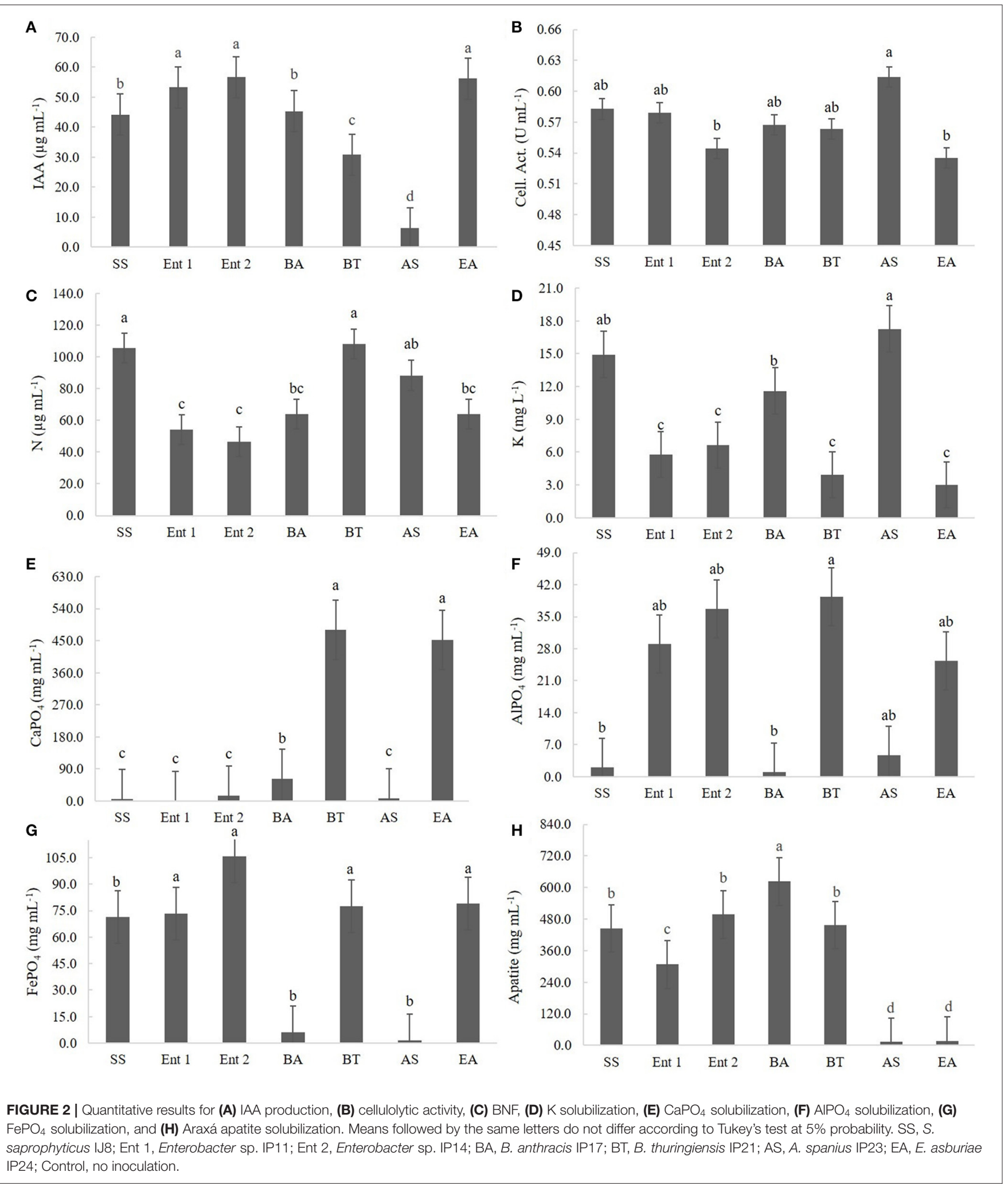

\section{Greenhouse Tests}

Plant Height

The plants inoculated with the bacteria $B$. thuringiensis $(112 \mathrm{~cm})$, Enterobacter $1(111 \mathrm{~cm})$, and E. asburiae $(111 \mathrm{~cm})$ were taller than the control plants $(108 \mathrm{~cm})(p<0.05)$; no significant differences were observed between the control plants and those inoculated with S. saprophyticus $(110 \mathrm{~cm})$, Enterobacter $2(109 \mathrm{~cm}), B$. anthracis $(109 \mathrm{~cm})$, and A. spanius $(108 \mathrm{~cm})$ (Figure 3A). 


\section{Number of Tillers}

There was no significant difference regarding the number of tillers between the treated plants $(p>0.05)$ and the control plants except for plants treated with Enterobacter 2, which exhibited fewer tillers than the control plants (Figure 3B).

\section{Diameter of Tillers}

There was no difference between the control and treated plants regarding the diameter of tillers, except for plants treated with $S$. saprophyticus $(1.4 \mathrm{~cm})$, Enterobacter $1(1.4 \mathrm{~cm}), B$. thuringiensis $(1.3 \mathrm{~cm})$, and E. asburiae $(1.3 \mathrm{~cm})$ (Figure $3 \mathrm{C})$.

\section{Root, Shoot, and Total Dry Matter}

Regarding shoot dry matter, higher values were found for plants inoculated with Enterobacter $2(12 \mathrm{~cm}), B$. anthracis $(11 \mathrm{~cm})$, and A. spanius $(11 \mathrm{~cm})$ than for the control plants $(9 \mathrm{~cm})(p<$ 0.01 ), while no differences were found between plants inoculated with B. thuringiensis $(9 \mathrm{~cm})$, Enterobacter $1(8.5 \mathrm{~cm})$, and $S$. saprophyticus compared to the control (Figure 3D).

Regarding root dry matter, plants treated with $B$. anthracis $(16 \mathrm{~cm}), B$. thuringiensis $(15 \mathrm{~cm})$, Enterobacter $1(14 \mathrm{~cm})$, and $A$. spanius $(13 \mathrm{~cm})$ showed higher values than the control plants $(11 \mathrm{~cm})$, whereas plants treated with $S$. saprophyticus $(10 \mathrm{~cm})$. Enterobacter $1(11 \mathrm{~cm})$ and E. asburiae $(11 \mathrm{~cm})$ had lower values than the control plants (Figure 3E).

\section{Total Dry Matter}

Regarding total dry matter, higher values were observed for plants treated with B. anthracis $(27 \mathrm{~cm})$, Enterobacter $2(26 \mathrm{~cm})$, Enterobacter $1(25 \mathrm{~cm})$, and A. spanius $(25 \mathrm{~cm})$ than for the

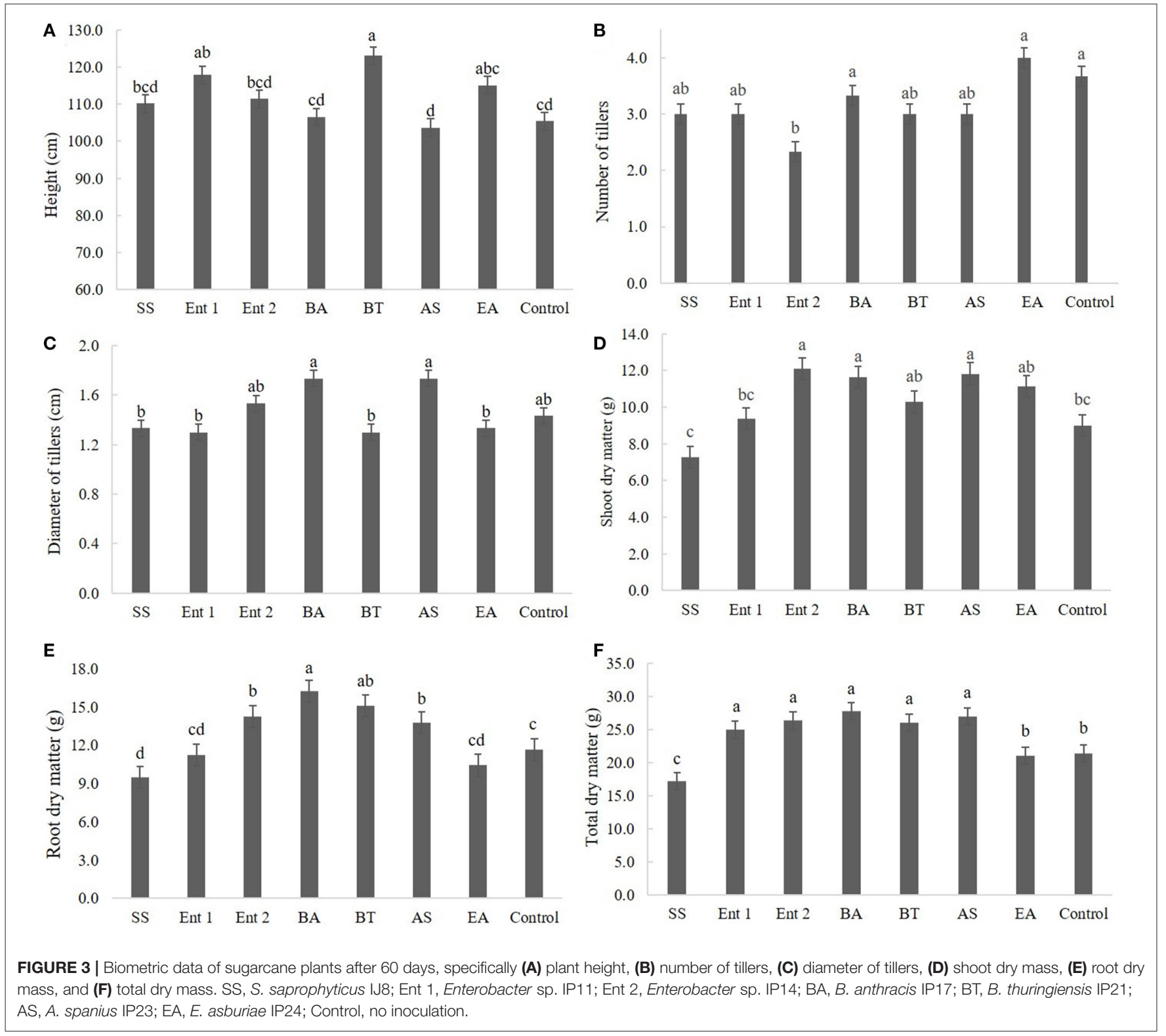



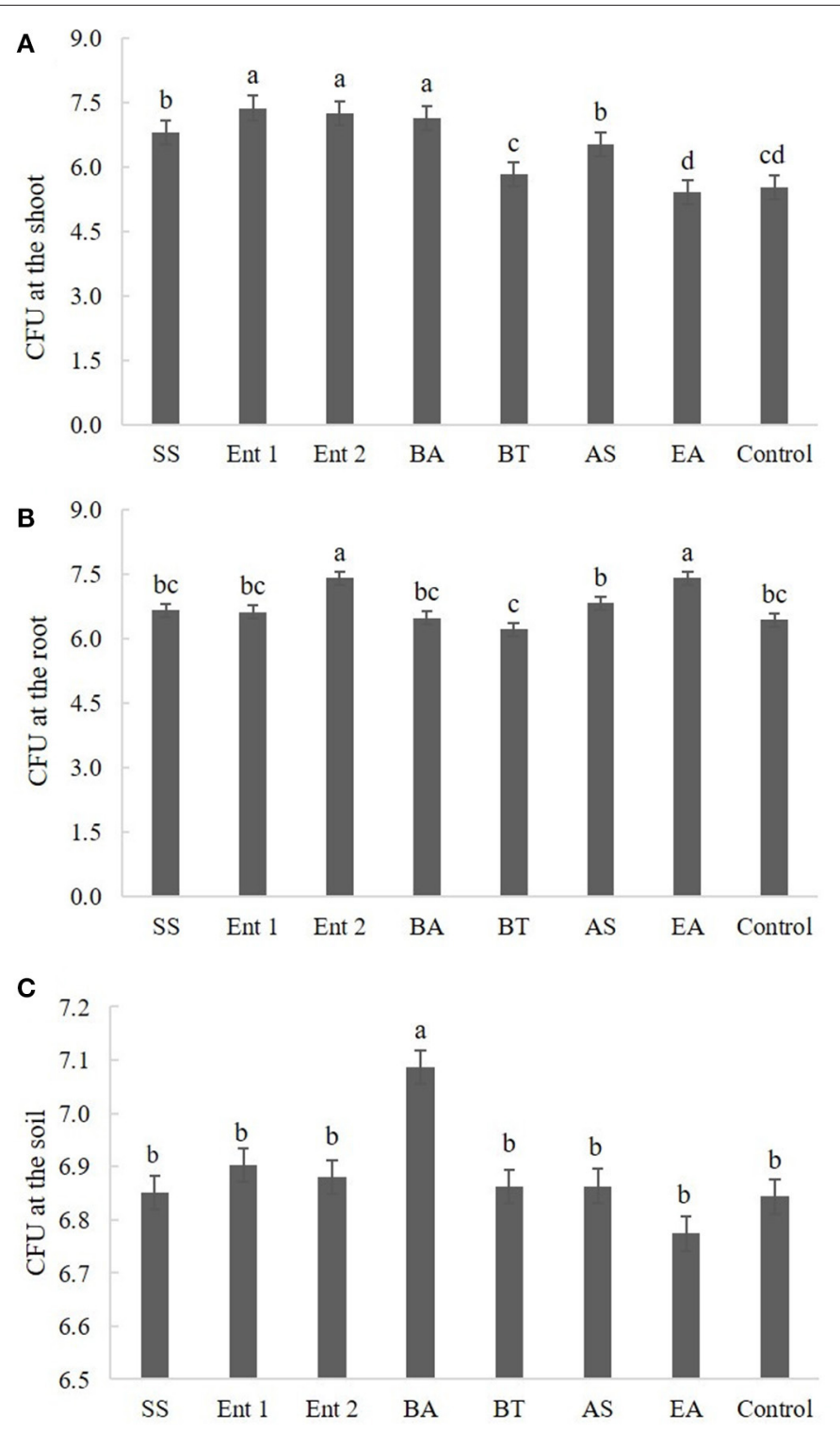

FIGURE 4 | Number of CFUs (A) endophytic in sugarcane shoots, (B) endophytic in sugarcane roots, and (C) on the soil. The data were transformed to log 10.

control plants $(24 \mathrm{~cm})(p<0.05)$, whereas lower values were observed for plants treated with $S$. saprophyticus $(17 \mathrm{~cm})$ and $E$. asburiae $(17 \mathrm{~cm})$ than for the control plants (Figure 3F).

\section{Colony Forming Units (CFUs) (Log10)}

Plants treated with Enterobacter 1 (8.0), Enterobacter 2 (8.0), B. anthracis (7.5), S. saprophyticus (6.8), and A. spanius (6.8) showed more CFUs at the shoot than the control plants (6.0). The number of CFUs at the shoot for plants treated with B. thuringiensis (6.0) and E. asburiae (6.0) was not different from that for the control plants (Figure 4A).

Regarding CFUs at the root, higher values were found for plants treated with Enterobacter 2 (7.5) and E. asburiae (7.2) than for the control plants (6.5). Plants treated with S. saprophyticus
(6.8), Enterobacter 1 (6.7), B. anthracis (6.4), B. thuringiensis (6.5), and A. spanius (6.5) did not differ from the control plants in this measure $(p>0.05)$ (Figure 4B).

Regarding CFUs in the soil, the only plants that presented higher values than the control plants $(p<0.05)$ were those treated with $B$. anthracis (7.1). The plants treated with other bacteria did not differ from the control plants (Figure 4C).

\section{Nitrogen and Phosphorus Extraction}

Regarding nitrogen extracted from the shoot, higher values $(p<0.05)$ were observed for plants treated with $B$. anthracis (140.0 mg), A. spanius (135.4 mg), E. asburiae $(134.2 \mathrm{mg})$, and Enterobacter $2(133.2 \mathrm{mg})$ than for the control plants $(75 \mathrm{mg})$. Nitrogen extracted from plants treated with $S$. 


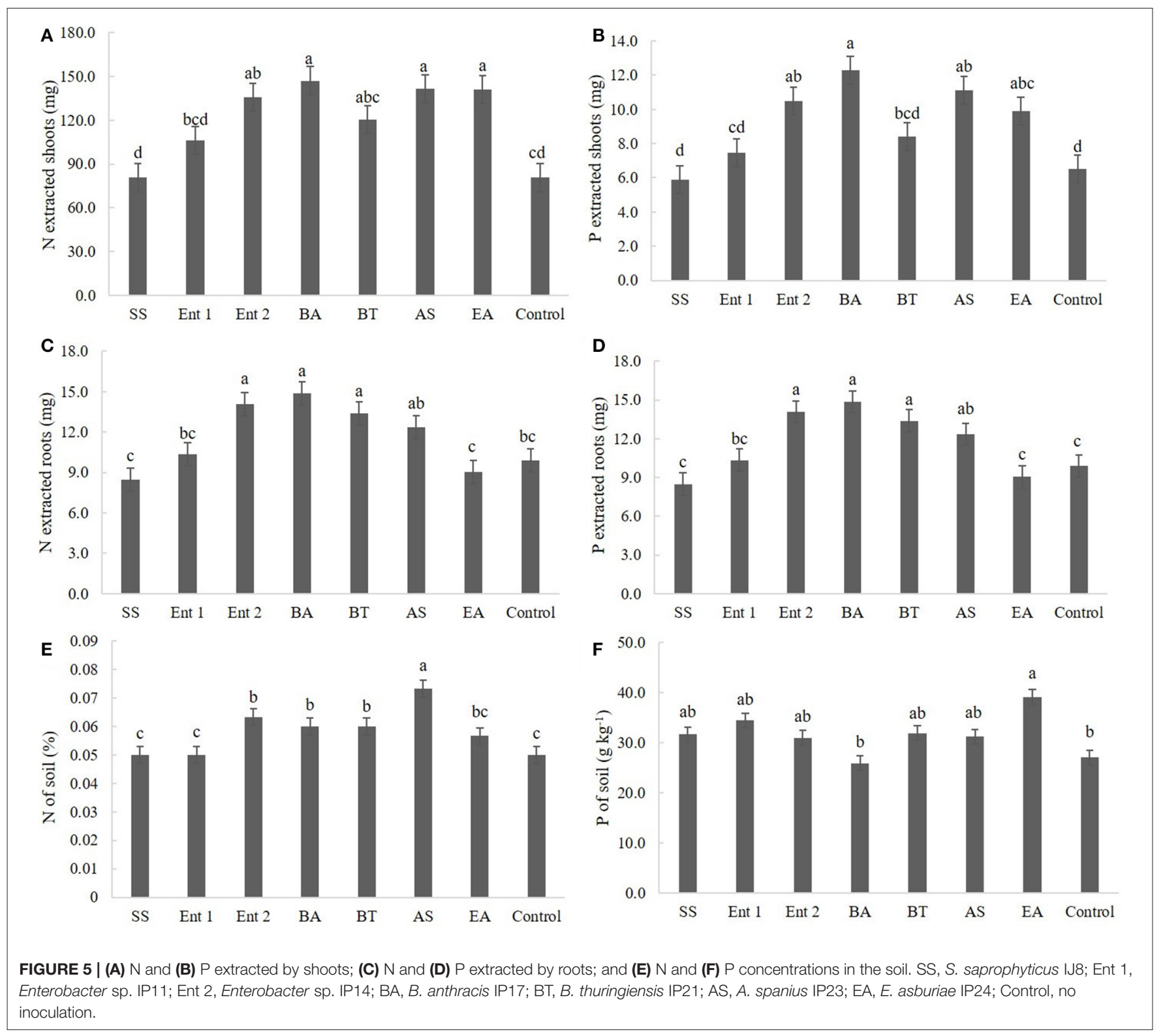

saprophyticus (80 $\mathrm{mg})$, Enterobacter 1 (100 $\mathrm{mg})$, and $B$. thuringiensis $(115 \mathrm{mg})$ did not differ from that extracted from the control plants (Figure 5A).

Regarding phosphorus extracted from the shoot, the plants that presented higher amounts than the control plants $(6 \mathrm{mg})$ were those inoculated with $B$. anthracis $(12 \mathrm{~cm}), A$. spanius $(11 \mathrm{mg})$, and E. asburiae $(11 \mathrm{mg})$. Plants inoculated with S. saprophyticus $(6.0 \mathrm{mg})$, Enterobacter $1(7.5 \mathrm{mg})$, and $B$. thuringiensis $(8.0 \mathrm{mg})$ did not show different levels of extracted phosphorus $(p>0.05)$ compared to the control plants (Figure 5B).

Regarding nitrogen extracted from the root, higher values $(p<0.05)$ were observed for plants inoculated with $B$. anthracis $(14 \mathrm{mg}), B$. thuringiensis $(13.0 \mathrm{~cm})$, and Enterobacter $2(14.0 \mathrm{mg})$ than for the control plants $(11 \mathrm{mg})$. The levels of nitrogen extracted from the root did not differ between plants inoculated with S. saprophyticus (8.4 mg), Enterobacter 1 (10.0 mg), A. spanius (12 mg), and E. asburiae and the control plants (Figure 5C).

Regarding phosphorus extracted from the root, higher values $(p<0.05)$ were observed for plants treated with $B$. anthracis (15.0 mg), B. thuringiensis $(14.0 \mathrm{mg})$, Enterobacter $2(14.0 \mathrm{mg})$, and A. spanius $(120.0 \mathrm{mg})$ than for the control plants $(11.0 \mathrm{mg})$. The levels of phosphorus extracted from the root did not differ $(p$ $>0.05$ ) between plants inoculated with S. saprophyticus $(80 \mathrm{mg})$, Enterobacter $1(100 \mathrm{mg})$, and E. asburiae $(9.0 \mathrm{mg})$ and the control plants (Figure 5D).

Regarding nitrogen extracted from the soil, higher values $(p<$ $0.05)$ were observed for plants treated with $A$. spanius $(0.07 \%)$, Enterobacter $2(0.68 \%), B$. anthracis $(0.06 \%)$, and B. thuringiensis $(0.06 \%)$ than for the control plants $(0.05 \%)$. The levels of nitrogen extracted from the soil did not differ $(p>0.05)$ between plants 
inoculated with S. saprophyticus (0.05\%), Enterobacter 1 (0.05\%), and E. asburiae (0.05\%) and the control plants (Figure 5E).

Regarding phosphorus extracted from the soil, higher values $(p<0.05)$ were observed for plants inoculated with E. asburiae $\left(39.5 \mathrm{~g} \mathrm{~kg}^{-1}\right)$ than for the control plants $\left(30 \mathrm{~g} \mathrm{~kg}^{-1}\right)$. The levels of phosphorus extracted from the soil did not differ between plants inoculated with S. saprophyticus $\left(33 \mathrm{~g} \mathrm{~kg}^{-1}\right)$, Enterobacter $1\left(35 \mathrm{~g} \mathrm{~kg}^{-1}\right)$, Enterobacter $2\left(36 \mathrm{~g} \mathrm{~kg}^{-1}\right)$, B. anthracis $\left(28 \mathrm{~g} \mathrm{~kg}^{-1}\right)$, $B$. thuringiensis $\left(32 \mathrm{~g} \mathrm{~kg}^{-1}\right)$, and $A$. spanius $\left(33 \mathrm{~g} \mathrm{~kg}^{-1}\right)$ and the control plants (Figure 5F).

\section{DISCUSSION}

Seven bacterial strains isolated from sugarcane were used in the present study, each of which previously showed some ability to promote plant growth.

E. asburiae isolated from the mustard rhizosphere showed the ability to solubilize phosphate, to produce siderophores and IAA and to resist fungicides (Ahemad and Khan, 2010). Mahdi et al. (2020) isolated E. asburiae from Chenopodium quinoa Willd, and this bacterium showed properties related to siderophore production, hydrogen cyanide ( $\mathrm{HCN})$, ammonia and extracellular enzymes. Interestingly, the plants that received inoculated E. asburiae showed high Na tolerance.

$B$. anthracis, the organism that causes anthrax, derives its name from the Greek word for coal, B. anthracis, because of its ability to cause black, coal-like cutaneous eschars (Helgason et al., 2000). As a result, this bacterium cannot be used as an inoculant despite being isolated from the sugarcane rhizosphere and presenting a good ability to promote root growth.

$B$. thuringiensis $(\mathrm{Bt})$ bacteria are insect pathogens that rely on insecticidal pore forming proteins known as Cry and Cyt toxins to kill their insect larval hosts (Bravo et al., 2011). In the present study, the isolate of $B$. thuringiensis showed the capacity to produce IAA. Similar results were found by Raddadi et al. (2008), who found, for the first time, an isolate able to produce ACC deaminase, phosphate enzyme and IAA.

Bacterial isolates able to produce IAA and solubilize phosphorous are interesting because phytohormones promote root cell proliferation and increase nutrient and water absorption through the overproduction of side cells and root hairs (Glick, 2012). In addition, phosphorus-solubilizing microorganisms are important in agricultural ecosystems and directly or indirectly influence physical, chemical, and biological soil properties (Hammer et al., 2011; Cordero et al., 2012; Verma et al., 2017).

S. saprophyticus is uniquely associated with uncomplicated urinary tract infection (UTI) in humans and has special urotropic and ecologic features that are different from those of other staphylococci and E. coli (Kuroda et al., 2005). Similar to B. anthracis, this bacterium cannot be used as an inoculant.

A. spanius, a gram-negative, rod-shaped bacterium isolated from members of the Arabidopsis thaliana rhizosphere, has been identified in various environments, including freshwater and soil isolates (Coenye et al., 2003; Li et al., 2018). The genome of $A$. spanius has attracted attention because preliminary screening has shown that it possesses the attributes of plant growth-promoting rhizobacteria, such as phosphate solubilization, indole-3-acetic acid biosynthesis, and siderophore production abilities, as well as actinomycete activity against Phytophthora cinnamomi in plants (Rosli, 2016). This is the first report showing the abilities of $A$. spanius to promote the growth of sugarcane crops.

Colonization of the rhizosphere or some plant tissues is the first step required for bacteria to have a plant growth effect. Interestingly, $B$. thuringiensis presented a low plant growth effect at the shoot, root and soil levels. This result suggests that the capacity for interaction with the plant is more important than the bacterial amount. Lobo et al. (2019) reported that some $B$. subtilis strains showed high amounts in the rhizosphere and did not promote plant growth, whereas other strains showed low amounts and promoted plant growth.

The present study has shown that some bacteria isolated from sugarcane are capable of metabolizing unavailable forms of soil nutrients to release them for plant uptake and produce IAA. In natural ecosystems, most nutrients, such as N, P, and S, are linked to organic molecules and therefore are minimally available to plants. To access these nutrients, plants depend on the growth of soil microorganisms such as bacteria and fungi that exhibit metabolic mechanisms for depolymerizing and mineralizing the organic forms of N, P, and S (Jacoby et al., 2017).

Growth promotion of sugarcane could be optimized with appropriate combinations of PGPRs, environmental conditions and plant genotypes. In this sense, efforts must be made in the development of good inoculants.

\section{CONCLUSIONS}

Enterobacter sp. IP11, Enterobacter sp. IP14, B. thuringiensis IP21, A. spanius IP23, and E. asburiae IP24 have the ability to promote the growth of sugarcane plants under greenhouse conditions. However, because Enterobacter sp. IP11, Enterobacter sp. IP14, and E. asburiae can be potentially pathogenic to humans, $B$. thuringiensis and A. spanius are feasible for use as future inoculants in sugarcane cultivation and may increase the potential to achieve production benefits.

\section{DATA AVAILABILITY STATEMENT}

The original contributions presented in the study are included in the article/supplementary material, further inquiries can be directed to the corresponding author.

\section{AUTHOR CONTRIBUTIONS}

All authors listed have made a substantial, direct and intellectual contribution to the work, and approved it for publication.

\section{FUNDING}

This work was carried out with support from the Coordination for the Improvement of Higher Education Personnel - Brazil (CAPES) - Financing Code 001. 


\section{REFERENCES}

Ahemad, M., and Khan, M. S. (2010). Plant growth promoting activities of phosphatesolubilizing Enterobacter asburiae as influenced by fungicides. EurAsian J. BioSci. 4, 88-95. doi: 10.5053/ejobios.2010.4.0.11

Ahemad, M., and Kibret, M. (2014). Mechanisms and applications of plant growthpromoting rhizobacteria: current perspective. J. King Saud Univ. - Sci. 26, 1-20. doi: 10.1016/j.jksus.2013.05.001

Alquéres, S., Meneses, C., Rouws, L., Rothballer, M., Baldani, I., Schmid, M., et al. (2013). The bacterial superoxide dismutase and glutathione reductase are crucial for endophytic colonization of rice roots by Gluconacetobacter diazotrophicus PAL5. Mol. Plant-Microbe Interact. 26, 937-945. doi: 10.1094/MPMI-12-12-0286-R

Altschul, S. F., Gish, W., Miller, W., Myers, E. W., and Lipman, D. J. (1990). Basic local alignment search tool. J. Mol. Biol. 215, 403-410. doi: 10.1016/S0022-2836(05)80360-2

Barbosa, J. C., and Maldonado, J. W. (2010). AgroEstat: sistema para análises estatísticas de ensaios agronômicos. Versão 1.0. Jaboticabal: FUNEP.

Batista, B. D., Bonatelli, M. L., and Quecine, M. C. (2021). Fast screening of bacteria for plant growth promoting traits. Methods Mol. Biol. 2232, 61-75. doi: 10.1007/978-1-0716-1040-4_7

Beauregard, P. B., Chai, Y., Vlamakis, H., Losick, R., and Kolter, R. (2013). Bacillus subtilis biofilm induction by plant polysaccharides. Proc. Natl. Acad. Sci. U. S. A. 110, E1621-E1630. doi: 10.1073/pnas.1218984110

Boiero, L., Perrig, D., Masciarelli, O., Penna, C., Cassán, F., and Luna, V. (2007). Phytohormone production by three strains of Bradyrhizobium japonicum and possible physiological and technological implications. Appl. Microbiol. Biotechnol. 74, 874-880. doi: 10.1007/s00253-006-0731-9

Bravo, A., Likitvivatanavong, S., Gill, S. S., and Soberón, M. (2011). Bacillus thuringiensis: a story of a successful bioinsecticide. Insect Biochem. Mol. Biol. 41, 423-431. doi: 10.1016/j.ibmb.2011.02.006

Coenye, T., Vancanneyt, M., Falsen, E., Swings, J., and Vandamme, P. (2003). Achromobacter insolitus sp. nov. and Achromobacter spanius sp. nov., from human clinical samples. Int. J. Syst. Evol. Microbiol. 53, 1819-1824. doi: 10.1099/ijs.0.02698-0

Conab (2019). Conab - Safra Brasileira de Cana-de-açúcar. Bol. Cana 4 Levant. 18-19. Available online at: https://www.conab.gov.br/info-agro/safras/cana (accessed February 21, 2019).

Cordero, O. X., Ventouras, L. A., DeLong, E. F., and Polz, M. F. (2012). Public good dynamics drive evolution of iron acquisition strategies in natural bacterioplankton populations. Proc. Natl. Acad. Sci. U. S. A. 109, 20059-20064. doi: 10.1073/pnas.1213344109

Danhorn, T., and Fuqua, C. (2007). Biofilm formation by plant-associated bacteria. Аnnu. Rev. Microbiol. 61, 401-422. doi: 10.1146/annurev.micro.61.080706.093316

Dar, S. A., Bhat, R. A., Dervash, M. A., Dar, Z. A., and Dar, G. H. (2021). "Azotobacter as biofertilizer for sustainable soil and plant health under saline environmental conditions," in Microbiota and Biofertilizers, eds K. R. Hakeem, G. H. Dar, M. A. Mehmood, and R. A. Bhat (Cham: Springer), 231-254. doi: 10.1007/978-3-030-48771-3_14

dos Santos, R. M., Diaz, P. A. E., Lobo, L. L. B., and Rigobelo, E. C. (2020). Use of plant growth-promoting rhizobacteria in maize and sugarcane: characteristics and applications. Front. Sustain. Food Syst. 4, 1-15. doi: 10.3389/fsufs.2020. 00136

Estrada-Bonilla, G. A., Durrer, A., and Cardoso, E. J. (2021). Use of compost and phosphate-solubilizing bacteria affect sugarcane mineral nutrition, phosphorus availability, and the soil bacterial community. Appl. Soil Ecol. 157:103760. doi: 10.1016/j.apsoil.2020.103760

Gaind, S. (2016). Phosphate dissolving fungi: mechanism and application in alleviation of salt stress in wheat. Microbiol. Res. 193, 94-102. doi: 10.1016/j.micres.2016.09.005

Ghose, T. K. (1987). Measurement of cellulase activities. Pure Appl. Chem. 59, 257-268. doi: 10.1351/pac198759020257

Glick, B. R. (1995). The enhancement of plant growth by free-living bacteria. Can. J. Microbiol. 41, 109-117. doi: 10.1139/m95-015

Glick, B. R. (2012). Plant growth-promoting bacteria: mechanisms and applications. Scientifica 2012:15. doi: 10.6064/2012/963401
Glick, B. R. (2014). Bacteria with ACC deaminase can promote plant growth and help to feed the world. Microbiol. Res. 169, 30-39. doi: 10.1016/j.micres.2013.09.009

Gururani, M. A., Upadhyaya, C. P., Baskar, V., Venkatesh, J., Nookaraju, A., and Park, S. W. (2013). Plant growth-promoting rhizobacteria enhance abiotic stress tolerance in Solanum tuberosum through inducing changes in the expression of ROS-scavenging enzymes and improved photosynthetic performance. J. Plant Growth Regul. 32, 245-258. doi: $10.1007 / \mathrm{s} 00344-012-9292-6$

Hall, T. A. (1999). BioEdit: a user-friendly biological sequence alignment editor and analysis program for Windows 95/98/NT. Nucl. Acids Symp. Ser. 41, 95-98.

Hammer, E. C., Nasr, H., Pallon, J., Olsson, P. A., and Wallander, H. (2011). Elemental composition of arbuscular mycorrhizal fungi at high salinity. Mycorrhiza 21, 117-129. doi: 10.1007/s00572-010-0316-4

Helgason, E., Økstad, O. A., Caugant, D. A., Johansen, H. A., Fouet, A., Mock, M., et al. (2000). Bacillus anthracis, Bacillus cereus, and Bacillus thuringiensisone species on the basis of genetic evidence. Appl. Environ. Microbiol. 66, 2627-2630. doi: 10.1128/AEM.66.6.2627-2630.2000

$\mathrm{Hu}, \mathrm{X}$., Chen, J., and Guo, J. (2006). Two phosphate- and potassium-solubilizing bacteria isolated from Tianmu Mountain, Zhejiang, China. World J. Microbiol. Biotechnol. 22, 983-990. doi: 10.1007/s11274-006-9144-2

IAC (2001). Análise química para avaliação da fertilidade de solos tropicais. Campinas: Instituto Agronômico.

Jacoby, R., Peukert, M., Succurro, A., Koprivova, A., and Kopriva, S. (2017). The role of soil microorganisms in plant mineral nutrition-current knowledge and future directions. Front. Plant Sci. 8:1617. doi: 10.3389/fpls.2017.01617

Jha, Y., Subramanian, R. B., and Patel, S. (2011). Combination of endophytic and rhizospheric plant growth promoting rhizobacteria in Oryza sativa shows higher accumulation of osmoprotectant against saline stress. Acta Physiol. Plant 33, 797-802. doi: 10.1007/s11738-010-0604-9

Kaymak, H., Yarali, F., Guvenc, I., and Donmez, M. (2008). The effect of inoculation with plant growth rhizobacteria (PGPR) on root formation of mint (Mentha piperita L.) cuttings. African J. Biotechnol. 7, 4479-4483.

Kuroda, M., Yamashita, A., Hirakawa, H., Kumano, M., Morikawa, K., Higashide, M., et al. (2005). Whole genome sequence of Staphylococcus saprophyticus reveals the pathogenesis of uncomplicated urinary tract infection. Proc. Natl. Acad. Sci. U.S.A. 102: 13272-13277. doi: 10.1073/pnas.05029 50102

Leite, M. C. de B. S., Pereira, A. P. de A., Souza, A. J. de, Andrade, P. A. M. de, Barbosa, M. V., Andreote, F. D., et al. (2018). Potentially diazotrophic endophytic bacteria associated to sugarcane are effective in plant growthpromotion. J. Exp. Agric. Int. 21, 1-15. doi: 10.9734/JEAI/2018/39963

Li, G., Yang, L., Zhang, T., Guo, X., Qin, J., Cao, Y., et al. (2018). Complete genome sequence of Achromobacter spanius type strain DSM 23806T, a pathogen isolated from human blood. J. Glob. Antimicrob. Resist. 14, 1-3. doi: 10.1016/j.jgar.2018.05.003

Lobo, L. L. B., Santos, R. M., and Rigobelo, E. C. (2019). Promotion of maize growth using endophytic bacteria under greenhouse and field conditions. AJCS 13, 1835-2707. doi: 10.21475/ajcs.19.13.12.p2077

Mahdi, I., Fahsi, N., Hafidi, M., Allaoui, A., and Biskri, L. (2020). Plant growth enhancement using rhizospheric halotolerant phosphate solubilizing bacterium Bacillus licheniformis QA1 and Enterobacter asburiae QF11 isolated from Chenopodium quinoa wild. Microorganisms. 8, 1-21. doi: 10.3390/microorganisms 8060948

Malavolta, E., Vitti, G. C., and Oliveira, S. A. (1989). Avaliação do estado nutricional das plantas: princípios e aplicações. Piracicaba: Potafos.

Mantelin, S., and Touraine, B. (2004). Plant growth-promoting bacteria and nitrate availability: impacts on root development and nitrate uptake. J. Exp. Bot. 55, 27-34. doi: 10.1093/jxb/erh010

Meneses, C. H. S. G., Rouws, L. F. M., Simões-Araújo, J. L., Vidal, M. S., and Baldani, J. I. (2011). Exopolysaccharide production is required for biofilm formation and plant colonization by the nitrogen-fixing endophyte Gluconacetobacter diazotrophicus. Mol. Plant-Microbe Interact. 24, 1448-1458. doi: 10.1094/MPMI-05-11-0127

Miliute, I., Buzaite, O., Baniulis, D., and Stanys, V. (2015). Bakteriniu endofitu reikšme Žemes ukio augalu atsparumui stresui: apŽvalga. Zemdirbyste 102, 465-478. doi: 10.13080/z-a.2015.102.060 
Miller, G. L. (1959). Use of dinitrosalicylic acid reagent for determination of reducing sugar. Anal. Chem. 31, 426-428. doi: 10.1021/ac60147a030

Moutia, J. F. Y., Saumtally, S., Spaepen, S., and Vanderleyden, J. (2010). Plant growth promotion by Azospirillum sp. in sugarcane is influenced by genotype and drought stress. Plant Soil 337, 233-242. doi: 10.1007/s11104010-0519-7

Nadeem, S. M., Ahmad, M., Zahir, Z. A., Javaid, A., and Ashraf, M. (2014). The role of mycorrhizae and plant growth promoting rhizobacteria (PGPR) in improving crop productivity under stressful environments. Biotechnol. Adv. 32, 429-448. doi: 10.1016/j.biotechadv.2013.12.005

Nahas, E., Centurion, J. F., and Assis, L. C. (1994). Microrganismos solubilizadores de fosfato e produtores de fosfatases de vários solos. Soc. Bras. Ciência do Solo $18,43-48$.

Nautiyal, C. S. (1999). An efficient microbiological growth medium for screening phosphate solubilizing microorganisms. FEMS Microbiol. Lett. 170, 265-270. doi: 10.1111/j.1574-6968.1999.tb13383.x

Pachaiyappan, S., and Janarthanam, B. (2007). Solubilization of potassium containing minerals by bacteria and their effect of plant growth wastewater treatments view project biochar production view project. World J. Agric. Sci. 3, 350-355. Available online at: https://www.researchgate.net/publication/ 236846002 (accessed November 26, 2019).

Patel, T. S., and Desai, P. B. (2015). Isolation and screening of pgpr from rhizospheric and nonrhizospheric soil of bt-cotton. J. Agric. Vet. Sci. Available online at: http://www.iajavs.com/currentissue.php (accessed March 3, 2020).

Pérez-Montaño, F., Alías-Villegas, C., Bellogín, R. A., Del Cerro, P., Espuny, M. R., Jiménez-Guerrero, I., et al. (2014). Plant growth promotion in cereal and leguminous agricultural important plants: from microorganism capacities to crop production. Microbiol. Res. 169, 325-336. doi: 10.1016/j.micres.2013.09.011

Raddadi, N., Cherif, A., Boudabous, A., and Daffonchio, D. (2008). Screening of plant growth promoting traits of Bacillus thuringiensis. Ann. Microbiol. 58, 47-52. doi: 10.1007/BF03179444

Raij, B. V., Cantarella, H., Quaggio, J. A., and Furlani, A. M. C. (1997). Recomendações de adubação e calagem para o estado de São Paulo, Campinas: Instituto Agronômico/FUNDAG, 1-88.

Ramachandra, M., Crawford, D. L., and Pometto, A. L. (1987). Extracellular enzyme activities during lignocellulose degradation by Streptomyces spp.: a comparative study of wild-type and genetically manipulated strains. Appl. Environ. Microbiol. 53, 2754-2760. Available online at: http:// www.ncbi.nlm.nih.gov/pubmed/16347492 (accessed November 26, 2019). doi: 10.1128/AEM.53.12.2754-2760.1987

Ramakrishna, W., Yadav, R., and Li, K. (2019). Plant growth promoting bacteria in agriculture: two sides of a coin. Agric. Ecosyst. Environ. Appl. Soil Ecol. 138, 10-18. doi: 10.1016/j.apsoil.2019.02.019

Riaz, U., Murtaza, G., Anum, W., Samreen, T., Sarfraz, M., and Nazir, M. Z. (2021). "Plant growth-promoting rhizobacteria (PGPR) as biofertilizers and biopesticides," in Microbiota and Biofertilizers, eds K. R. Hakeem, G. H. Dar, M. A. Mehmood, and R. A. Bhat (Cham: Springer), 181-196. doi: 10.1007/978-3-030-48771-3_11

Rosli, A. R. B. (2016). Biodiscovery of Plant Growth-Promoting Rhizobacteria and Their Role in Plant-Microbe Interactions. Brisbane, QLD: The University of Queensland.

Sambrook, J., Fritsch, E. F., and Maniatis, T. (1989). Molecular Cloning: A Laboratory Manual. New York, NY: Cold Spring Harbor Laboratory Press.
Sarwar, M., and Kremer, R. J. (1995). Determination of bacterially derived auxins using a microplate method. Lett. Appl. Microbiol. 20, 282-285. doi: 10.1111/j.1472-765X.1995.tb00446.x

Sheoran, N., Valiya Nadakkakath, A., Munjal, V., Kundu, A., Subaharan, K., Venugopal, V., et al. (2015). Genetic analysis of plant endophytic Pseudomonas putida BP25 and chemo-profiling of its antimicrobial volatile organic compounds. Microbiol. Res. 173, 66-78. doi: 10.1016/j.micres.2015.02.001

Silva Filho, G. N., and Vidor, C. (2000). Solubilização de fostatos por microrganismos na presença de fontes de carbono. Rev. Bras. Ciência do Solo 24,311-319. doi: 10.1590/S0100-06832000000200008

Tamura, K., Nei, M., and Kumar, S. (2004). Prospects for inferring very large phylogenies by using the neighbor-joining method. Proc. Natl. Acad. Sci. U. S. A. 101, 11030-11035. doi: 10.1073/pnas.0404206101

Tedesco, M. J., Gianello, C., Biassani, C. A., and Bohnen, H. (1995). Análises de solo, plantas e outros materiais. Porto Alegre: Departamento de solos da UFRGS.

Vacheron, J., Desbrosses, G., Bouffaud, M. L., Touraine, B., Moënne-Loccoz, Y., Muller, D., et al. (2013). Plant growth-promoting rhizobacteria and root system functioning. Front. Plant Sci. 4:356. doi: 10.3389/fpls.2013.00356

Verma, B. R. M. R., Meena, M. L. D. V. S., and Deewan, M. J. P. (2017). Enhancing production potential of cabbage and improves soil fertility status of indogangetic plain through application of bio-organics and mineral fertilizer. Int J. Curr. Microbiol. Appl. Sci. 6, 301-309. doi: 10.20546/ijcmas.2017.603.033

Vieira, F. C. S., and Nahas, E. (2005). Comparison of microbial numbers in soils by using various culture media and temperatures. Microbiol. Res. 160, 197-202. doi: 10.1016/j.micres.2005.01.004

Vurukonda, S. S. K. P., Giovanardi, D., and Stefani, E. (2018). Plant growth promoting and biocontrol activity of Streptomyces spp. as endophytes. Int. J. Mol. Sci. 19:952. doi: 10.3390/ijms19040952

Wilkinson, K. G., Dixon, K. W., and Sivasithamparam, K. (1989). Interaction of soil bacteria, mycorrhizal fungi and orchid seed in relation to germination of Australian orchids. New Phytol. 112, 429-435. doi: 10.1111/j.1469-8137.1989.tb00334.x

Wollum, A. (1982). "Cultural methods for soil microorganisms," in Methods of Soil Analysis, eds D. R. A. L. Miller and R. H. Keeney, (Madison, WI: A. L. Page), 781-802. doi: 10.2134/agronmonogr9.2.2ed.c37

Yoorin (2018). Fornecendo nutrientes para aumentar sua produtividade. Available online at: http://www.yoorin.com.br/pt/produtos/ekosil (accessed May 16, 2018).

Zhou, D., Huang, X. F., Chaparro, J. M., Badri, D. V., Manter, D. K., Vivanco, J. M., et al. (2016). Root and bacterial secretions regulate the interaction between plants and PGPR leading to distinct plant growth promotion effects. Plant Soil 401, 259-272. doi: 10.1007/s11104-015-2743-7

Conflict of Interest: The authors declare that the research was conducted in the absence of any commercial or financial relationships that could be construed as a potential conflict of interest.

Copyright (c) 2021 Santos and Rigobelo. This is an open-access article distributed under the terms of the Creative Commons Attribution License (CC BY). The use, distribution or reproduction in other forums is permitted, provided the original author(s) and the copyright owner(s) are credited and that the original publication in this journal is cited, in accordance with accepted academic practice. No use, distribution or reproduction is permitted which does not comply with these terms. 